\title{
Sucrose metabolizing enzymes in cell suspension cultures of Bauhinia forficata, Curcuma zedoaria and Phaseolus vulgaris ${ }^{(1)}$
}

\author{
Marcia Ometto de Mello(2) ${ }^{(2 n t o ̂ n i o ~ F r a n c i s c o ~ d e ~ C a m p o s ~ A m a r a l(2) ~ a n d ~ M u r i l o ~ M e l o(2) ~}$
}

\begin{abstract}
The objective of this work was to study the activity of sucrose metabolizing enzymes in extracts of cell suspension cultures of Bauhinia forficata Link, Curcuma zedoaria Roscoe and Phaseolus vulgaris L. Invertase pathway was identified in the three studied species. Sucrose synthase pathway was also responsible for sucrose metabolism in Curcuma zedoaria and Phaseolus vulgaris cells. Activity values higher than $300 \mathrm{nmol} \mathrm{min} \mathrm{mg}^{-1}$ of protein were found for acid and neutral invertases, UDPglucose pyrophosphorylase and phosphoglucomutase in the cell extract of the three plant species. Sucrose synthase showed low activity in Bauhinia forficata cells. As sucrose concentration in the culture medium decreased, sucrose synthase activity increased in C. zedoaria and P. vulgaris cells. The glycolytic enzymes activity gradually reduced at the end of the culture period, when carbohydrate was limited.
\end{abstract}

Index terms: fructokinase, glycolysis, tissue culture.

\section{Enzimas do metabolismo da sacarose em cultura celular de Bauhinia forficata, Curcuma zedoaria e Phaseolus vulgaris}

Resumo - O objetivo deste trabalho foi estudar as enzimas do metabolismo da sacarose em culturas de célula em suspensão de Bauhinia forficata Link, Curcuma zedoaria Roscoe e Phaseolus vulgaris L. A via da invertase foi identificada nas três espécies estudadas. A via da sacarose sintase também foi responsável pelo metabolismo da sacarose em células de Curcuma zedoaria e Phaseolus vulgaris. Foram encontradas atividades maiores que $300 \mathrm{nmol} \mathrm{min}^{-1} \mathrm{mg}^{-1}$ de proteína das enzimas invertase ácida e alcalina, UDPglicose pirofosforilase e fosfoglicomutase no extrato celular das três espécies de plantas. A sacarose sintase mostrou atividade baixa nas células de Bauhinia forficata. À medida que a concentração de sacarose no meio de cultura diminuiu, a atividade da sacarose sintase aumentou em células de Curcuma zedoaria e Phaseolus vulgaris. Ao final do período de cultura, quando os carboidratos se tornaram limitantes, as atividades das enzimas glicolíticas reduziram-se gradualmente.

Termos para indexação: frutofuranosidase, glicólise, cultura de tecidos.

\section{Introduction}

Sucrose is the most common sugar translocated in plants and it often represents over $95 \%$ of the dry weight of translocated materials (Zimmermann \& Ziegler, 1975). It has also been widely used as the

(1) Accepted for publication on October 24, 2000 Supported by Fapesp.

(2)Escola Superior de Agricultura Luiz de Queiroz, Centro de Biotecnologia Agrícola, Dep. de Ciências Biológicas, Av. Pádua Dias, 11, CEP 13418-900 Piracicaba, SP E-mail: momello@carpa.ciagri.usp.br, t-amaral@mail.com, mmelo@carpa.ciagri.usp.br sole carbohydrate source of plant culture medium including those used for Curcuma (Dekkers et al., 1991; Barthakur \& Bordoloi, 1992), Bauhinia (Kumar, 1992; Upreti \& Dhar, 1996) and the Phaseolus (Dillen et al., 1996; Barros et al., 1997) genus.

Even though carbohydrates are of prime importance for cell growth, maintenance and differentiation in vitro, the fundamental aspects of carbon utilization and metabolism in cell and tissue cultures have yet to be fully understood (Romano et al., 1995; Vu et al., 1995).

Plant cell and tissue culture metabolize sucrose to provide energy and carbon skeletons for every metabolic process that the cell will conduct. There 
are two pathways for the enzymatic cleavage of sucrose (Sung et al., 1988; Vu et al., 1995): first, in what is called classic pathway, the invertase reaction produces glucose and fructose with the loss of the glycosidic energy bond. These products must be phosphorylated by glucokinase and fructokinase prior to subsequent metabolization (Huber \& Akazawa, 1986); second, in what is called alternative pathway, sucrose synthase cleaves sucrose into fructose and UDPglucose, therefore conserving the energy of the glycosidic bond (Sung et al., 1988). The generated UDPglucose feeds glucose 1-phosphate directly into glycolysis by the reaction catalyzed by UDPglucose pyrophosphorylase. This pathway is dependent upon UDP and pyrophosphate (Black et al., 1987; Xu et al., 1989 ) and was firstly proposed to operate in plants in 1986 (Huber \& Akazawa, 1986; Sung et al., 1986). While the invertase pathway requires two nucleotides triphosphate for the production of two hexose phosphates, the sucrose synthase pathway requires only one.

Another important step in the sucrose metabolism is the interconvertion of fructose 6-phosphate and fructose 1,6-biphosphate. In this case, two alternatives are also known (Sung et al., 1989). One alternative is catalyzed by the irreversible nucleotide triphosphate-dependent phosphofructokinase (PFK) that is described as a maintenance reaction (Boll, 1991). The second is catalyzed by a readily reversible pyrophosphate-dependent phosphofructokinase (PFP) that is described as an adaptative pathway, in which an equilibrium reaction conserves energy through the utilization and synthesis of pyrophosphate (Black et al., 1987; Boll, 1991). So PFP when working in the gluconeogenic direction could produce PPi to drive sucrose breakdown through UDPglucose pyrophosphorylase (Xu et al., 1989). An understanding of sucrose metabolism in plant tissue and cell cultures has become very important since it is a plant heterotrophic metabolism and more and more alternative carbon sources, other than sucrose, have been used and they may act as a cell differentiation inducer (Frick, 1994). A comparison of the enzymatic processes by which plant cells assimilate and metabolize different carbon sources may contribute to the comprehension of the morphogenetic process in vitro.
Most of sucrose metabolism research has been performed by using tissue from plants growing in environmental conditions where the synthesized sucrose is for translocation and storage, different from the present study situation, by using cell suspension cultures, where sucrose is promptly broken down for energy and carbon skeleton.

The present work aimed to study the sucrose metabolism in cell suspension cultures of Bauhinia forficata Link, Curcuma zedoaria Roscoe and Phaseolus vulgaris.

\section{Material and Methods}

Hypocotil segments $(1 \mathrm{~cm})$ of B. forficata plants obtained from seeds germinated in vitro were inoculated on a half strength MS culture medium (Murashige \& Skoog, $1962)$ supplemented with sucrose $(3 \%$, w/v) and $17.8 \mu \mathrm{M}$ of BAP for callus induction.

C. zedoaria calli were obtained by inoculating root segments of in vitro micropropagated plants on MS culture medium (Murashige \& Skoog, 1962) supplemented with sucrose $(3 \%, w / v), 13.4 \mu \mathrm{M}$ of NAA and $2.2 \mu \mathrm{M}$ of BAP.

P. vulgaris embryos after appropriate asepsis were inoculated on MS culture medium (Murashige \& Skoog, 1962) supplemented with $3 \%$ sucrose (w/v) and $22.6 \mu \mathrm{M}$ 2,4-D for callus induction.

All mediums were solidified with $2.3 \mathrm{~g} \mathrm{~L}^{-1}$ of Phytagel (Sigma) and adjusted to $\mathrm{pH} 5.8$ with $0.1 \mathrm{M} \mathrm{KOH}$ before autoclaving at $120^{\circ} \mathrm{C}$ for 30 minutes. Cultures were maintained at $25 \pm 2^{\circ} \mathrm{C}$ under a 16 hour photoperiod $\left(50.8 \pm 6.6 \mu \mathrm{mol} \mathrm{m}^{-2} \mathrm{~s}^{-1}\right)$ by using cool-white fluorescent lamps, General Electric/40W (B. forficata and P. vulgaris) or under darkness (C. zedoaria). Transfers were carried out at every 30 days intervals for 6 months.

Suspension cultures for all the three plant species were initiated by culturing fragmented callus $(0.5 \mathrm{~g})$ in $125 \mathrm{~mL}$ Erlenmeyer flasks containing $10 \mathrm{~mL}$ of the same callus inducing medium composition but liquid. The flasks were maintained under agitation on rotatory shaker at 60 cycles $\mathrm{min}^{-1}$ at the same conditions as described for the callus cultures. Subcultures were carried out at 3 weeks intervals for 3 months.

At selected interval of time $(0,5,10,15,20,25,30$, 35,40 and 45 days) samples of cell suspension cultures (four flasks of each treatment) were taken and vacuum filtered through Watman number one paper filter and transferred to a tared aluminum can. After determination of the fresh weight, the cells were frozen dried at $-50^{\circ} \mathrm{C}$ for 
24 hours in a freeze dryer (4.5 Labcon) and weighted. Growth curves based on fresh and dry matter accumulation for culturing period of 45 days were determined.

For the enzymes assays, the frozen dried cell samples were hand homogenized by using pistil and mortar in liquid nitrogen in presence of ice cold $200 \mathrm{mM}$ pH 7.8 HEPES/KOH buffer, containing $3 \mathrm{mM}$ of EDTANa $2.2 \mathrm{H}_{2} \mathrm{O}, 3 \mathrm{mM}$ of magnesium acetate, $10 \mathrm{mM}$ of dithiothreitol (DTT) and 1\%(w/v) of polyvinylpyrrolidone (PVP). The homogenate was centrifuged $(10,000 \mathrm{~g})$ for 20 minutes at $4^{\circ} \mathrm{C}$ and the supernatant was used directly as enzyme and protein sources. Samples used correspond to the time intervals of $0,15,30$ and 40 days of culture.

All biochemicals used for enzyme assays were obtained from Sigma Chemical Company (USA).

All enzymes were assayed by monitoring the change in absorbance at $340 \mathrm{~nm}$. Assays were performed at $25^{\circ} \mathrm{C}$ in a final volume of $1 \mathrm{~mL}$. Linearity was observed before the enzyme reaction initiation. Activity is expressed as nmol min-1 $\mathrm{mg}^{-1}$ of protein. The activity of invertase (EC 3.2.1.26) at pH 5.0 and 7.0 (Xu et al., 1989), sucrose synthase (EC 2.4.1.13) (Sung et al., 1989), hexokinase (EC 2.7.1.2) (Huber \& Akazawa, 1986), fructokinase (EC 2.7.1.4) (Huber \& Akazawa, 1986), UDPglucose pyrophosphorylase (EC 2.7.7.9) (Huber \& Akazawa, 1986), phosphoglucomutase (EC 2.7.5.1) (Doehlert et al., 1988), PFK (EC 2.7.1.11) (Sung et al., 1989) and PFP (EC 2.7.1.90) (Xu et al., 1986) was assayed. Protein was determined according to Bradford (1976).

The experiments consisted of three treatments (plant specie) distributed into four blocks (repetitions) in factorial design. A regression analysis testing polynomial models was performed and the best model was chosen based on the maximum $\mathrm{R}^{2}$ (the coefficient of determination) significative value. The analysis was based on the mean values of the treatments on each sampling time by the Excell and the Statistical Analysis System (SAS Institute, 1996).

\section{Results and Discussion}

The utilization pattern of the exogenous sucrose supplement by the cell suspensions was related to the studied specie. B. forficata had the lowest growth rate and $P$. vulgaris the highest, based on both fresh and dry matter accumulation (Figures 1 and 2). C. zedoaria showed a typical growth curve for fresh and dry matter accumulation characterized by a lag phase of 10 days, where the cells were adapting to the new medium, followed by a log phase of around
20 days with intensive growth and ending with stabilization of the growth. The end of the growth period was followed by a decrease of the accumulated matter, probably caused by the exhaustion of sucrose or accumulation of toxic substances in the culture medium. Both B. forficata and P. vulgaris did not show

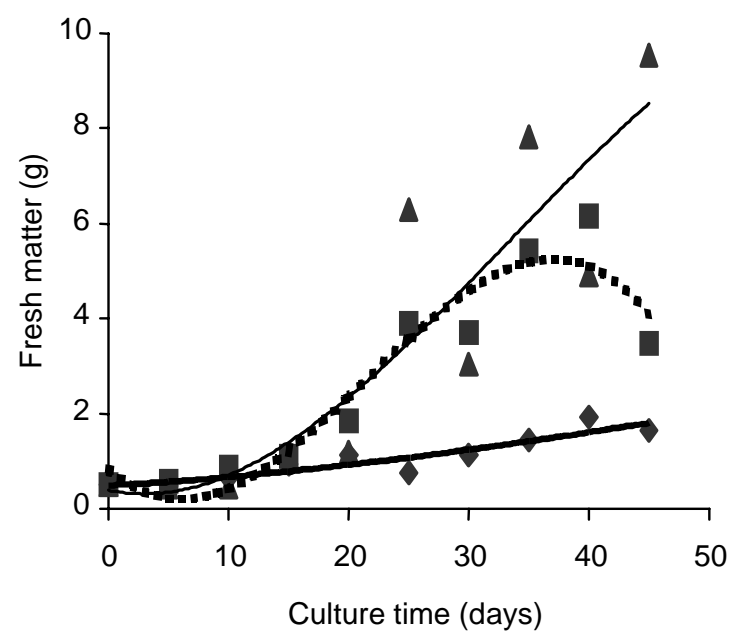

Figure 1. Fresh matter accumulation by Bauhinia forficata $(\diamond)\left(\mathrm{R}^{2}=0.8541\right)$, Curcuma zedoaria $(\square)\left(\mathrm{R}^{2}=0.9186\right)$ and Phaseolus vulgaris $(\mathbf{\Delta})\left(\mathrm{R}^{2}=0.9111\right)$ in cell suspension cultures.

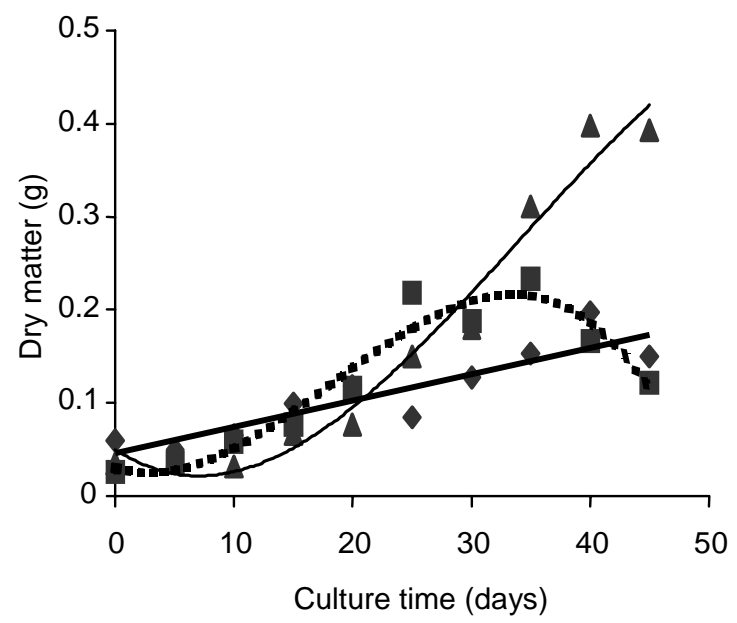

Figure 2. Dry matter accumulation by Bauhinia forficata $(\diamond)\left(\mathrm{R}^{2}=0.8101\right)$, Curcuma zedoaria $(\mathbf{\square})\left(\mathrm{R}^{2}=0.9307\right)$ and Phaseolus vulgaris $(\mathbf{\Delta})\left(\mathrm{R}^{2}=0.9692\right)$ in cell suspension cultures. 
the complete log phase and the stabilization of growth even after being cultured for 45 days. P. vulgaris showed a longer lag phase (15 days) than $C$. zedoaria. B. forficata did not show a well defined lag phase, since its growth was linear.

The protein accumulation pattern (Figure 3) followed the model observed for other cultured cells. The highest protein accumulation rate corresponds to the growth curve inflexion point. An interesting finding is that even though $B$. forficata and $P$. vulgaris cells did not accumulate dry matter to attain the full growth curve, they accumulated protein in a fashion similar to $C$. zedoaria cells. Taking in account that $P$. vulgaris cells growth curve, even at 45 days of culturing, are still showing the final part of the $\log$ phase, but already attained the maximum protein accumulation, it can be suggested that the cells' protein content is already set before the full cell growth rate is attained. This together with the absence of growth curve definition for $B$. forficata cells and the protein accumulation curve for these cells; one can propose that protein accumulation by cell suspension culture can be used as a reliable parameter to monitor plant cells growth in suspension culture.

Cell suspension cultures of all three plant species contain all three enzymes to break down sucrose to its hexose units: sucrose synthase, acid and neutral invertases, also sufficient activities of the required

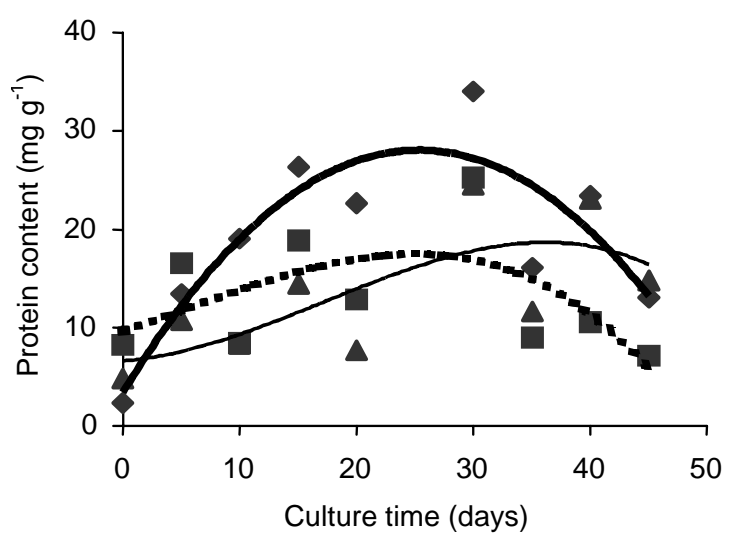

Figure 3. Soluble protein accumulation by Bauhinia forficata $(\bullet)\left(\mathrm{R}^{2}=0.6138\right)$, Curcuma zedoaria $(\mathbf{\square})$ $\left(\mathrm{R}^{2}=0.3334\right)$ and Phaseolus vulgaris $(\mathbf{\Delta})\left(\mathrm{R}^{2}=0.3535\right)$ in cell suspension cultures. enzymes to carry on the first part of glycolise producing triose phosphates from hexoses (Table 1). However, cell culture of $B$. forficata does not seem to rely on sucrose synthase to cleave sucrose, since its activity was quite low (lower than $9 \mathrm{nmol} \mathrm{min}-1 \mathrm{mg}^{-1}$ of protein) all over the growth cycle. This together with the also low activity found for UDPglucose pyrophosphorylase consist on evidence that $B$. forficata metabolizes sucrose mainly by the invertase (classic) pathway. On the other hand, C. zedoaria and $P$. vulgaris presented activities of the enzymes sucrose synthase, acid invertase, neutral invertase and UDPglucose pyrophosphorylase consistent with the metabolization of sucrose by the classic and by the alternative pathways.

Catabolically speaking, cells from sucrose exporting tissue of plants metabolizing sucrose by the classic pathway are not supposed to show much activity of phosphoglucomutase. When sucrose is cleaved by invertases to produce glucose and fructose the monophosphate hexoses formed are glucose 6-phosphate and fructose 6-phosphate, but not glucose 1-phosphate. If any amount is formed it is due to the less used optional sucrose synthase action. However, cell cultures of $B$. forficata presents the highest activities of phosphoglucomutase all over the growth cycle. The metabolic and physiologic significance of this for B. forficata or for other plants showing the classic pathway is apparently not clear, even though glucose 1-phosphate is the key intermediate for biosynthesis of the entire family of sugars and polysaccharides.

Two spatially separated sets of the glycolytic pathway enzymes occur in plant cells, one in the cytoplasm and the other in chloroplast and in non-photosynthetic plastid. Metabolic studies showed that isolated plastids can degrade starch and form glycolytic metabolites as products. In non-photosynthetic plastids, hexose monophosphates are probably, in part, transferred from the plastids to the cytoplasm, since this organelle shows too low activity of the metabolism of hexose units to phosphoglycerate (Frehner et al., 1990) and does not contain phosphoglyceromutase (Sttit \& ApRees, 1979). Hexose monophosphate translocator has been documented and characterized in plants (Tetlow et al., 1996; Kammerer et al., 1998). 
To what extent the chloroplasts of tissue culture cells suspension can present non-photosynthetic behavior is a matter of discussion. The relatively high amount of exogenous sucrose in the growth media, the $\mathrm{CO}_{2}$ concentration available for the cells inside the culture flasks and the absence of chlorophyll would, at least, become the Calving Cycle inoperative. Therefore, the flux of monophosphate hexose, in and out, through the plastids membrane is a need. In, to have monophosphate hexose, mainly glucose 6-phosphate, to carry out the pentose phosphate shunt to fulfill the cells requirements for fatty acids and amino acids biosynthesis, and starch synthesis as well; out, to give continuation of utilization of any starch reserve by the chloroplast. Cell growth and differentiation in tissue culture has been reported to show intensive starch grain formation (Sharma et al., 1993). Therefore, the activity of phosphoglucomutase besides being necessary for sucrose and starch synthesis would function as a connection between monophosphate hexoses pool of the cytoplasm and that in the chloroplast.

To metabolize one molecule of sucrose to the level of triose-phosphate, 4 ATP are required in the invertase (classic) pathway. In the alternative pathway, the UDP consuming UDPglucose formed is converted by UDPglucose pyrophosphorylase to glucose 1-phosphate with the input of one PPi and the output of one UTP (Black et al., 1987). This UTP can be used to convert fructose to fructose 6-phosphate by fructokinase dependent on UTP, generating the UDP needed in the first reaction of this pathway. The PPi required in UDPglucose pyrophosphorylase reaction could come from cytoplasmic source evaluated in 0.04 to $0.08 \mathrm{mM}$ (Sung et al., 1988) or from the PFP reaction which interconvert fructose 1,6-biphosphate and fructose 6-phosphate (Figure 4). This furnishing phosphate reaction may counterbalance the non sense idea (futile cycle) from the interconvertion of fructose 6-phosphate and fructose 1,6-phosphate. Therefore, all this reaction forming triose phosphate from sucrose by the alternative pathway would expend only one phosphate bond.

It is still unknown how sucrose is partitioned between the two pathways in those plants possessing both of them. It is believed that it varies with the growth stage, function of the tissue or cell (Sung et al.,

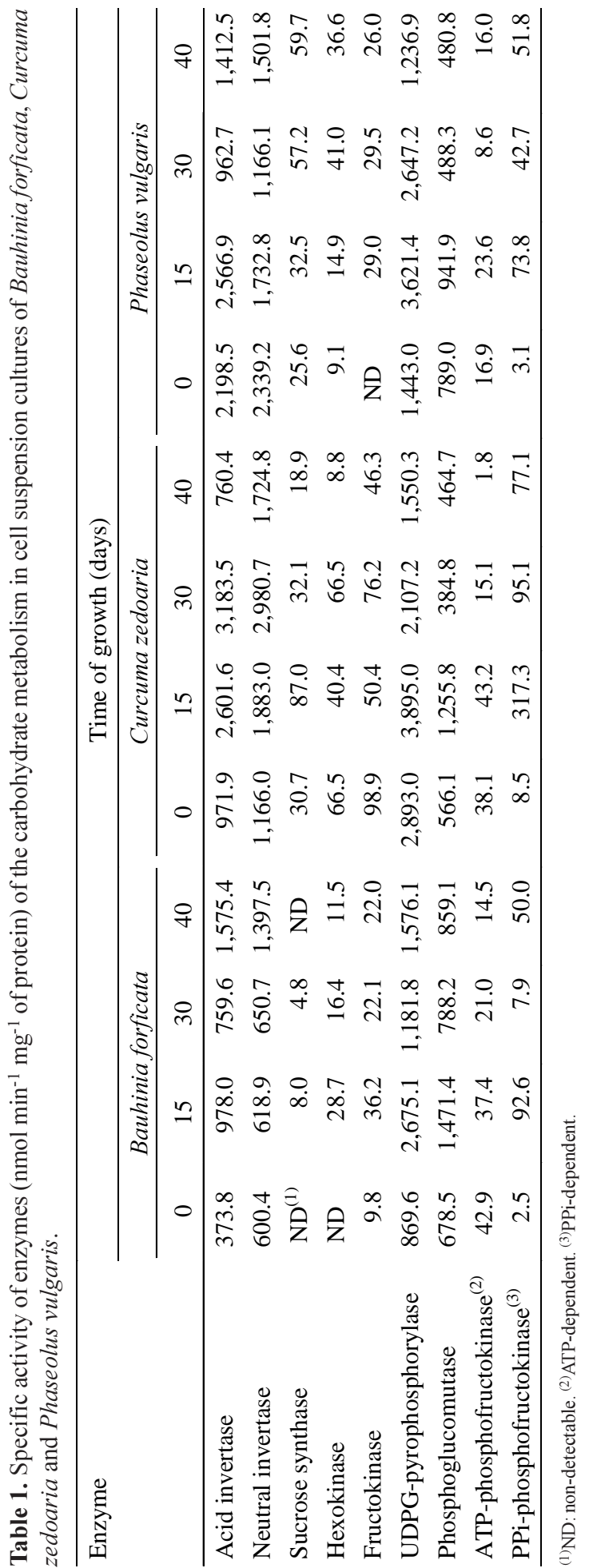

Pesq. agropec. bras., Brasília, v. 36, n. 9, p. 1085-1092, set. 2001 
1988) or even with the plant specie and sucrose concentration as it is shown in this work. B. forficata cells with a slow growth certainly did not consume much of the sucrose available in the culture medium, therefore explaining why this plant specie would not utilize the alternative pathway as much as the other two studied species.

After 30 days of culture, when C. zedoaria cells have already reached the maximum growth and started the stabilization phase, the activity of some enzymes started to decrease, and after 40 days of culture all the enzymes activity were low, as well. Considering that at this time most of the sucrose may have been consumed, the absence or low concentration of sugar would gradually affect the activity of the enzymes, suggesting a sensitive regulation of them by carbohydrate concentration. The regulation of invertases and sucrose synthase enzymes by sucrose concentration have been demonstrated in maize and this may be related to the adjustment of carbon resources allocation (Koch et al., 1992; Xu et al., 1996). According to the authors, invertases and sucrose synthase regulation genes fall into two classes with contrasting sugar responses. For both gene families, one of the classes is upregulated by the increase of carbohydrate concentration and the other class is repressed by sugars and upregulated by its absence.

$C$. zedoaria and $P$. vulgaris cell suspension cultures, that present the alternative pathway for sucrose breakdown showed invertases and sucrose synthase activities to be sucrose concentration dependent. This observation is in agreement with lower sucrose synthase $\mathrm{Km}$ value for sucrose compared to that for invertases and with the fact that sucrose synthase pathway is energetically more efficient than the invertase pathway, since one ATP molecules is spent when a

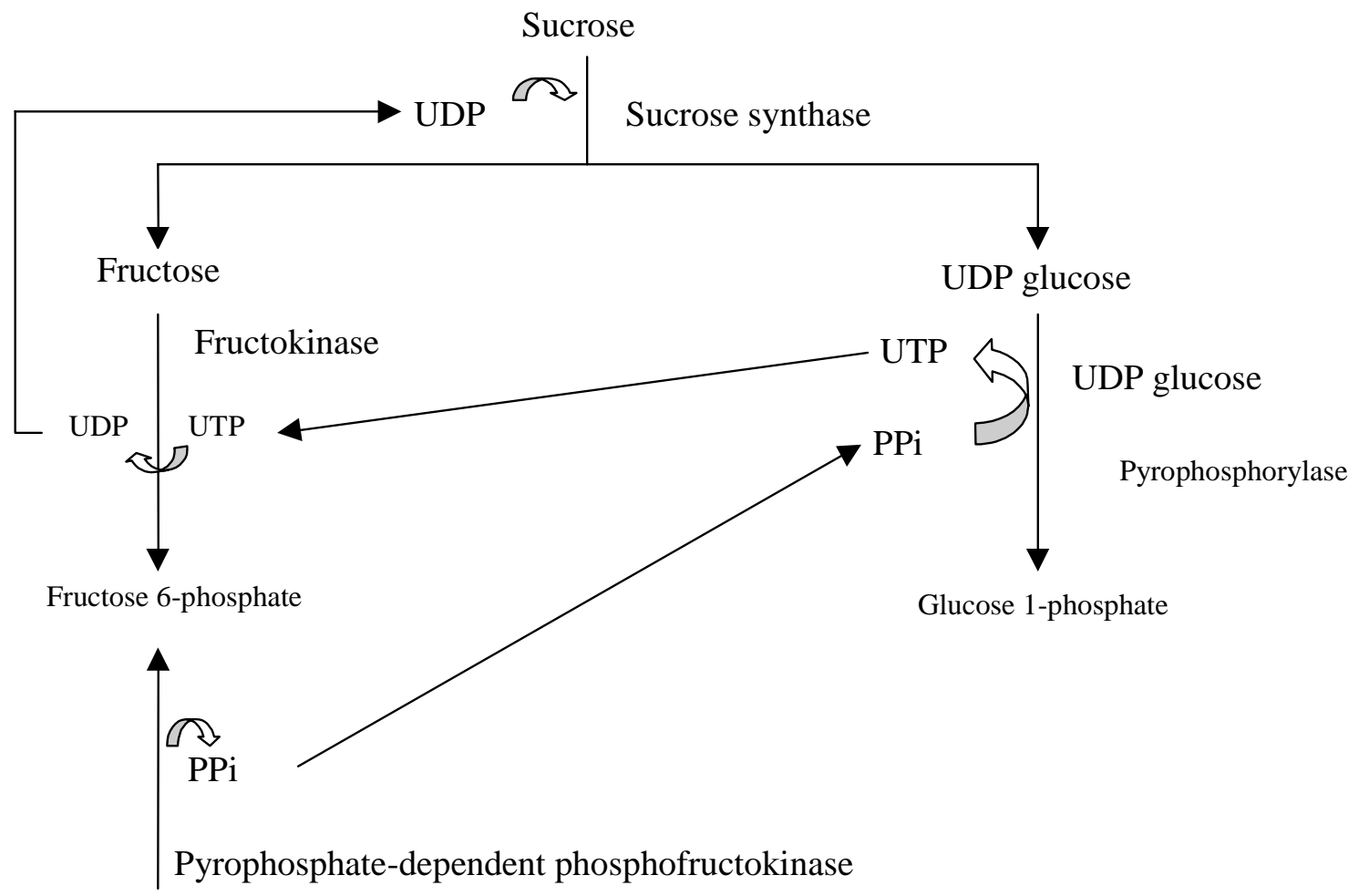

Fructose 1,6-biphosphate

Figure 4. Proposed degradation pathway for sucrose by sucrose synthase based on the alternative pathway. 
molecule of sucrose is metabolized to triose phosphate. These changes on invertases and sucrose synthase total activities are also connected to the previously mentioned fact that both enzymes gene families fall into two classes with contrasting sugar responses (Xu et al., 1996), what provides a potential mechanism for adjusting the sucrose metabolizing capacity of importing cells to levels of available carbon sources (Koch et al., 1992). Therefore, it is suggested that the alternative pathway is relatively more important when sucrose availability is limiting although both pathways still can exist in these conditions. This proposal is in agreement with the enzymes activities found for $B$. forficata. In this plant specie sucrose did not reach low concentration in the culture medium due to its smaller growth. So, low activity of the enzymes involved in the alternative pathway could be observed.

\section{Conclusions}

1. Glycolytic enzymes degrading sucrose to triose phosphate are present in cells suspension culture of all three studied plant specie; activity of sucrose synthase, UDPglucose pyrophosphorilase, phosphoglucomutase and pyrophosphate dependent phosphofructokinase show to be plant specie dependent.

2 . The enzymes activities indicate that $B$. forficata uses preferentially the classic and P. vulgaris and $C$. zedoaria the classic and alternative pathways to cleave sucrose to its hexose units.

3 . The comparison of the patterns of dry matter and protein accumulation for the three plant species, confirm the possibility of using protein accumulation to monitor cell growth in vitro.

4. Invertases and sucrose synthase activities show to be sucrose concentration dependent.

\section{Acknowledgments}

To the Fundação de Amparo à Pesquisa do Estado de São Paulo (Fapesp) for the financial support.

\section{References}

BARROS, L. M. G.; GAMA, M. I. C. S.; GONÇALVES, C. H. R. P.; BARRETO, C. C.; SANTANA, E. F.; CARNEIRO, V. T. C. Cultura de tecidos de feijoeiro visando à introdução de genes exógenos. Pesquisa Agropecuária Brasileira, Brasília, v. 32, n. 3, p. 267-275, mar. 1997.

BARTHAKUR, M. P.; BORDOLOI, D. N. Micropropagation of Curcuma amada. Journal of Spices and Aromatic Crops, Calicut, v. 1, n. 2, p. 154-159, 1992.

BLACK, C. C.; MUSTARDY, L.; SUNG, S. S.; KORMANIK, P. P.; XU, D. P.; PAZ, N. Regulation and roles for alternative pathways of hexose metabolism in plants. Physiologia Plantarum, Copenhagen, v. 69, p. 387-394, 1987.

BOLL, M. Activities and regulation of enzymes of carbohydrate metabolism in spruce (Picea abies). Zeitschrisft fuer Naturforschung Section C: a journal of biosciences, Tuebingen, v. 46c, p. 597-604, 1991.

BRADFORD, M. M. A rapid and sensitive method for the quantitation of microgram quantities of protein utilizing the principle of protein-dye binding. Analytical Biochemistry, San Diego, v. 72, p. 248-254, 1976.

DEKKERS, A. J.; RAO, A. N.; GOH, C. J. In vitro storage of multiple shoot cultures of gingers at ambient temperature of $24-29^{\circ} \mathrm{C}$. Scientia Horticulturae, Amsterdam, v. 47, p. $157-167,1991$.

DILLEN, W.; DECLERCQ, J.; MONTAGU, M. van; ANGENON, G. Plant regeneration from callus in a range of Phaseolus acutifolius A.: gray genotypes. Plant Science, Limerick, v. 118, n. 1, p. 81-88, 1996.

DOEHLERT, D. C.; KUO, T. M.; FELKER, F. C. Enzymes of sucrose and hexose metabolism in developing kernels of two inbreds of maize. Plant Physiology, Rockville, v. 86, p. 1013-1019, 1988.

FREHNER, M.; POZUETA-ROMERO, J.; AKAZAWA, T. Enzyme sets of glycolysis, gluconeogenesis and oxidative pentose pathway are not complete in non-green highly purified amyloplasts of sycamore (Acer pseudoplatanus) cell suspensions. Plant Physiology, Rockville, v. 94, p. $538-544,1990$.

FRICK, H. Heterotrophy in the Lemnaceae. Journal of Plant Physiology, Jena, v. 144, p. 189-193, 1994.

HUBER, S. C.; AKAZAWA, T. A novel sucrose synthase pathway for sucrose degradation in cultured sycamore cells. Plant Physiology, Rockville, v. 81, p. 1008-1013, 1986.

KAMMERER, B.; FISHER, K.; HILPERT, B.; SCHUBERT, S.; GUTENSOHN, M.; WEBER, A.; FLUGGE, U. I. Molecular characterization of a carbon 
transporter in plastids from heterotrophic tissues: the glucose 6-phosphate antiporter. Plant Cell, Rockville, v. 10, p. 105-117, 1998.

KOCH, K. E.; NOLTE, K. D.; DUKE, E. R.; McCARTY, D. R.; AVIGNE, W. T. Sugar levels modulate differential expression of maize sucrose synthase genes. Plant Cell, Rockville, v. 4, p. 59-69, 1992

KUMAR, A. Micropropagation of a mature leguminous tree - Bauhinia purpurea. Plant Cell, Tissue and Organ Culture, v. 31, p. 257-259, 1992

MURASHIGE, T.; SKOOG, F. A revised medium for rapid growth and bioassays with tobacco tissue cultures. Physiologia Plantarum, v. 15, p. 473-497, 1962.

ROMANO, A.; NORONHA, C.; MARTINS-LOUÇÃO, M. A. Role of carbohydrates in micropropagation of cork oak. Plant Cell, Tissue and Organ Culture, Dordrecht, v. 40, n. 2 , p. $159-167,1995$.

SAS INSTITUTE (Cary, United States). SAS user's guide: Statistics. 6. ed. Cary, 1996. 956 p.

SHARMA, K. K.; YEUNG, E. C.; THORPE, T. A. Histology of shoot bud ontogeny from seedling root segments of Brassica napus L. Annals of Botany, London, v. 71, p. $461-466,1993$

STTIT, M.; ApREES, T. Capacities of pea chloroplasts to catalyze the oxidative pentose phosphate pathway and glycolysis. Phytochemistry, Oxford, v. 18, p. 1905-1911, 1979 .

SUNG, S. S.; KORMANIK, P. P.; XU, D. P.; BLACK, C. C. Sucrose metabolic pathways in sweetgum and pecan seedlings. Tree Physiology, Victoria, v. 5, p. 39-52, 1989.

SUNG, S. S.; XU, D. P.; ALVAREZ, C. A.; MUSTARDY, L. A.; BLACK, C. C. Pyrophosphate as a biosynthetic energy source and fructose 2,6-biphosphate regulation. In: HUNGARIAN - USA BINATIONAL SYMPOSIUM ON PHOTOSYNTHESIS, 1986, Newport.
Proceedings... Newport : Salve Regina College, 1986. p. $72-80$.

SUNG, S. S.; XU, D. P.; GALLOWAY, C. M.; BLACK, C. C. A reassessment of glycolysis and gluconeogenesis in higher plants. Physiologia Plantarum, Copenhagen, v. 72 , p. 650-654, 1988.

TETLOW, I. J.; BOWSHER, C. G.; EMES, M. J. Reconstitution of the hexose phosphate translocator from the envelope membranes of wheat endosperm amyloplasts. Biochemical Journal, London, v. 319, p. 717-723, 1996

UPRETI, J.; DHAR, U. Micropropagation of Bauhinia vahlii Wight \& Arnott - a leguminous liana. Plant Cell Reports, Berlin, v. 16, p. 250-254, 1996.

VU, J. C. V.; NIEDZ, R. P.; YELENOSKY, G. Activities of sucrose metabolism enzymes in glycerol-grown suspension cultures of sweet orange (Citrus sinensis L. Osbeck). Environmental and Experimental Botany, Oxford, v. 35, n. 4, p. 455-463, 1995.

XU, D. P.; SUNG, S. S.; ALVAREZ, C. A.; BLACK, C. C. Pyrophosphate-dependent sucrose metabolism and its activation by fructose 2,6 biphosphate in sucrose importing plant tissue. Biochemical and Biophysical Research Communications, San Diego, v. 141, n. 2, p. 440-445, 1986.

XU, D. P.; SUNG, S. S.; BLACK, C. C. Sucrose metabolism in lima bean seeds. Plant Physiology, Rockville, v. 89, p. 1106-1116, 1989.

XU, J.; AVIGNE, W. T.; McCARTY, D. R.; KOCH, K. E. A similar dichotomy of sugar modulation and development expression affects both paths of sucrose matabolism: evidence from maize invertase gene family. Plant Cell, Rockville, v. 8, p. 1209-1220, 1996.

ZIMMERMANN, M. H.; ZIEGLER, H. List of sugar alcohols in sieve-tube exudates. In: ZIMMERMANN, M. H.; MILBURN, J. A. (Ed.). Encyclopedia of plant physiology: new series. Berlin : Springer, 1975. v. 1, p. 480-503. 